\title{
IN FACT, IT'S A MATTER OF OPINION: DETERMINING A DISTINCTION BETWEEN FACT AND OPINION WITHIN THE NEW ZEALAND DEFENCE OF HONEST OPINION
}

\author{
Wendy J Riseley*
}

\begin{abstract}
This article discusses the distinction between fact and opinion within the defence of honest opinion. It is argued that the classic legal tests for determining that distinction are largely unhelpful and produce unpredictable results, which trigger a chilling effect on speech. This article advocates for an adaptation of the four-factor totality of circumstances test, established in Ollman v Evans, to be inserted into the Defamation Act 1992. This would provide more clarity, consistency and predictability for the defence of honest opinion in New Zealand, thereby better supporting freedom of expression under s 14 of the New Zealand Bill of Rights Act 1990.
\end{abstract}

\section{INTRODUCTION}

The common law defence of honest opinion to defamation proceedings provides a bulwark for one of society's most salient rights: freedom of expression. Whether a statement is held to be an opinion or a fact can make the difference between the defendant winning or having to pay damages. However, courts throughout the common law jurisdictions battle with the distinction. So murky and contentious is this boundary that it often seems that the only way to know if a statement is defamatory is to send it through the legal machine of the courts and see what emerges. The results can be baffling. In one case it was held defamatory to call someone "hideously ugly", ${ }^{1}$ in another for a food critic to describe the food as "inedible". ${ }^{2}$ In both instances the communicators felt they were simply voicing their opinions and should be free to do so. This uncertainty in the law can cause

* $\quad$ Article submitted as part of the LLB(Hons) programme at Victoria University of Wellington. I would like to thank my supervisor, Steven Price, for his helpful guidance and comments.

1 Berkoff v Burchill [1997] EMLR 139.

2 John Martin "The Blue Angel Defamation Trial" (1989) 11 Gazette of L\&J 13. 
people to check themselves to such an extent that free speech is hindered. The United Kingdom Court of Appeal recently widened the concept of opinion, stating that the lower Court's ruling against the defendant had "most certainly had a chilling effect on public debate". ${ }^{3}$

This article will argue that the current methods determining a dividing line between fact and opinion are unworkable because no bright-line exists. After a summary of the law surrounding the defence of honest opinion, the rationale behind protecting opinion is discussed. The article then looks at the inadequacy of the fact-opinion distinction and its inability to support that rationale. Finally, after a survey of some current legal tests, a more flexible and predictable eight-factor test is proposed to address the dichotomy and better support free speech.

\section{THE LAW OF HONEST OPINION}

The law of defamation aims to vindicate and prevent unjustified damage to reputations. In New Zealand, this endeavour comes by way of the common law and is supported by the Defamation Act 1992. While the statute does not supply a definition, Lord Atkin in Sim v Stretch described a defamatory statement as one that has a tendency to lower a person "in the estimation of rightthinking members of society generally". ${ }^{4}$ To help provide a balance protecting free speech, the law of defamation provides four defences: truth, honest opinion, and absolute and qualified privilege. ${ }^{5}$ The first two are relevant for the purposes of this article. The truth defence is available where the defendant has made a factual statement that he can prove true. The defence of honest opinion requires greater explanation. In essence, this defence protects an individual's ability to voice their opinions. While some courts argue that opinions should be protected because they are not defamatory, ${ }^{6}$ the English treatise, Gatley on Libel and Slander, considers it better to view opinion statements as defamatory but not actionable. ${ }^{7}$ This defence is subject to three limitations.

\section{A The Opinion Must Be Genuine}

Under s 10 of the Defamation Act 1992, the genuineness of the opinion is paramount. While a factual statement is objectively determined to be true or false, a defendant's genuine belief in their statement is a subjective test, concerned with his state of mind. ${ }^{8}$ The question the courts ask is

3 British Chiropractic Association v Singh [2010] EWCA Civ 350, [2011] 1 WLR 133 at [11].

4 Sim v Stretch [1936] 2 All ER 1237 at 1240.

5 Defamation Act 1992, ss 8, 9-12, 13-15, 16-19.

6 Campbell v Spottiswoode (1863) 3 B \& S 769; Minister of Justice v SA Associated Newspapers Ltd (1979) 3 SA 466.

7 Patrick Milmo and WVH Rodgers (eds) Gatley on Libel and Slander (11th ed, Sweet \& Maxwell, London, 2008) at [12.1].

8 John Burrows and Ursula Cheer Media Law in New Zealand (6th ed, LexisNexis, Wellington, 2010) at [3.2.3]. 
whether any man could honestly hold the views and express the opinion on those facts. ${ }^{9}$ This test is one of honesty, not of reasonableness. ${ }^{10}$ Thus, the question is not whether one agrees with the comment. The commentator may be prone to exaggeration or have obstinate, even prejudicial views. ${ }^{11}$ This will not in itself defeat the defence. Furthermore, proof of actual malice is not an exception to honesty. ${ }^{12}$ However, if sheer invective is used, this may be "compelling evidence" of a lack of genuine belief in the opinion. ${ }^{13}$ In addition, public interest is no longer a requirement. ${ }^{14}$ While important to note the element of honesty, it is the following two limitations that this paper is primarily concerned with.

\section{B The Opinion Must Be Clearly Opinion}

If the statement is a fact, the defence of honest opinion will not be available. Opinion has been described as "something which is or can reasonably be inferred to be a deduction, inference, conclusion, criticism, remark, observation, etc". ${ }^{15}$ It must be obvious to the reader ${ }^{16}$ that the statement is an opinion, ${ }^{17}$ but distinguishing between fact and opinion can be difficult. Currently, New Zealand courts often consider the contextual background of the statement to tell them how that statement would likely be interpreted: ${ }^{18}$

Presentation is crucial to whether a statement is or is not an expression of opinion.

.

The defence applies when the words appear to a reasonable reader to be conclusionary.

Similarly, courts in the United Kingdom often distinguish fact from opinion by a contextual analysis looking through the "prism of the reader". ${ }^{19}$ An unclear statement may simply be treated as

9 At [3.2.3], citing Lord Diplock in Associated Newspapers v Burstein [2007] EWCA Civ 600 at [519]-[520].

10 Mitchell $v$ Sprott [2002] 1 NZLR 766 (CA) at [24].

11 Merivale v Carson (1887) 20 QBD 275 at 281; Silkin v Beaverbrook Newspapers Ltd [1958] 2 All ER 516 at 520; Mitchell v Sprott, above n 10, at [24].

12 Defamation Act 1992, s 12.

13 Tse Wai Chun v Cheng [2000] HKCFA 86, [2001] EMLR 31 at [57].

14 Awa v Independent News Auckland Ltd [1997] 3 NZLR 590 (CA) at 595.

15 Clarke v Norton [1910] VLR 494 at 499.

16 References in this article to "reader", assume "listener" as well.

17 Burrows and Cheer, above n 8, at [3.2.2]. See also Hunt v Star Newspaper Co Ltd [1908] 2 KB 309 at 319.

18 Mitchell $v$ Sprott, above n 10, at [18-19]; Burrows and Cheer, above n 8, at [3.2.2].

19 Joseph $v$ Spiller [2010] UKSC 53, [2011] 1 AC 852 at 855. 
if it were a fact. ${ }^{20}$ John Burrows and Ursula Cheer identify some types of statements that can cause difficulties, including: those that mix together facts and opinion such that the opinion cannot be separated out; those that appear as fact but are conclusions inferred from facts; and those that appear as opinions but are not supported by any facts. ${ }^{21}$

\section{The Opinion Must Be Based On a Substratum of Facts}

Two conditions must exist for this element to be met. First, unless they are common knowledge, the facts on which the opinion is based must be stated. In this way, the reader can consider the communicator's opinion and compare it against his own. ${ }^{22}$ In Tse Wai Chun $v$ Cheng, Lord Nicholls established that the supporting facts must be sufficient for the reader to "judge for himself how far the comment was well founded". ${ }^{23}$ This test has now been altered to "whether the reader can recognise that what is being stated is comment". ${ }^{24}$

The facts set out need not be the entire facts, or else a theatre reviewer, for instance, would need to set out the entire script of a play. ${ }^{25}$ The subject matter need only be "indicated with sufficient clarity to justify the comment being made". ${ }^{26}$ If the facts on which the opinion is based are common knowledge, the reader will be able to determine if the opinion is justified without those facts being stated.

Secondly, the facts on which the opinion is based must be "proved true or not materially different from the truth". ${ }^{27}$ Two exceptions to this condition exist. ${ }^{28}$ If false facts are protected by privilege, then they may still support an honest opinion defence. Furthermore, if there are enough true facts stated or common knowledge to justify the opinion then not all facts supporting the opinion need to be true.

\footnotetext{
20 At 855.

21 Burrows and Cheer, above n 8, at [3.2.2]; see Part IV.B - Underlying Problem.

22 Burrows and Cheer, above $\mathrm{n}$ 8, at [3.2.1(a)].

23 Tse Wai Chun v Cheng [2000] HKCFA 86, [2001] EMLR 31 at [19].

24 Milmo and Rodgers, above n 7, at [12.8] discussing the test from Lowe v Associated Newspapers Ltd [2006] EWHC 320 (QB).

25 Gardiner v John Fairfax \& Sons Pty Ltd (1942) 42 SRNSW 171 at 179.

26 Burrows and Cheer, above n 8, at [3.2.1(a)]; Kemsley v Foot [1952] AC 345 at 347.

27 Mitchell v Sprott, above n 10, at [22]; Defamation Act 1992, s 11(a).

28 Burrows and Cheer, above $n$ 8, at [3.2.1(b)].
} 
The defendant's state of mind is relevant, as he "cannot rely on as support of his opinion any facts not in existence when it was made or of which he was not aware". ${ }^{29}$

This final limitation is closely connected with the earlier aim in assisting a reader to recognise a statement as opinion. With a substratum of facts set out, a statement will appear to the reader more like an opinion.

\section{New Zealand and United Kingdom Comparison}

While New Zealand defamation law regularly draws on law from the United Kingdom, there have been, and are, some important differences. Prior to the enactment of the Defamation Act 2013 (UK), the defence of honest opinion was called "honest comment". ${ }^{30}$ Public interest was a requirement under that defence. The new Act removes the public interest requirement and introduces a serious harm threshold, whereby the statement must meet that threshold before a claim for defamation can be brought to the courts. This raises the bar for claimants. ${ }^{31}$ Notably, privilege is extended to include peer-reviewed scientific and academic journals. ${ }^{32}$

\section{RATIONALE BEHIND THE HONEST OPINION DEFENCE}

The protection of honest opinion is a mainstay of freedom of expression. It is the "right of the citizen to express his genuine opinion ... however wrong or exaggerated or prejudiced that opinion may be". ${ }^{33}$ This defence supports overlapping arguments for freedom of expression, such as the search for truth, self-governance and the autonomy of the individual. In New Zealand, the right to free speech is embodied in s 14 of the New Zealand Bill of Rights Act 1990. It endorses "the freedom to seek, receive and impart information and opinions of any kind in any form". ${ }^{34}$ Under s 5 , this freedom is subject to reasonable limitations "demonstrably justified in a free and democratic society". ${ }^{35}$

29 Milmo and Rodgers, above n 7, at [12.3]. But see Defamation Act 2013 (UK), s 3(4); Timothy Pinto "Defamation Act 2013: A boost for free speech - Part 1: Serious Harm, Truth and Honest Opinion" (2013) Inforrm’s Blog: The International Forum for Responsible Media Blog <inforrm.wordpress.com>.

30 Joseph $v$ Spiller, above $\mathrm{n}$ 19, at [117]. For purposes of this article, which looks to various jurisdictions, the terms "fair comment" and "honest opinion" will be used interchangeably. But see, Milmo and Rodgers, above $\mathrm{n} 7$, at [12.6] for discussion regarding different implications of each term.

31 Defamation Act 2013 (UK) (explanatory notes) at 11.

32 Defamation Act 2013 (UK), s 6.

33 Telnikoff $v$ Matusevitch [1992] 2 AC 343 at 357. See also Gertz v Robert Welch Inc 418 US 323 (1974) at 339.

34 New Zealand Bill of Rights Act 1990, s 14

35 New Zealand Bill of Rights Act 1990, s 5. 


\section{A Marketplace of Ideas}

Safeguarding genuine opinions captures one of the key purposes behind free speech, namely to create a marketplace of ideas. ${ }^{36}$ These types of statements "support an unfettered interchange of ideas for the bringing about of political and social changes desired by people", ${ }^{37}$ and, thus, are in the public interest. ${ }^{38}$ As Learned Hand J remarked, "the right conclusions are more likely to be gathered out of a multitude of tongues". ${ }^{39}$ Notwithstanding the aim of "right conclusions", unpopular views can provide a useful backboard against which debate can arise. As such, the defence of honest opinion protects obstinate, exaggerated, even prejudiced views. The courts do not judge the reasonableness of the opinion. ${ }^{40}$

Similar to obstinate and prejudicial views, arguably false facts too have a purpose in society. They provide the stepping stones for discovery by stimulating debate in bringing about "the clearer perception and livelier impression of truth, produced by its collision with error". ${ }^{41}$ Dealing with the facts that underlie ideas, even if they are false, "bears a proportionate relationship" to the freedom to discuss those ideas. ${ }^{42}$

However, false facts that damage reputation may cross the line from the protection of s 14 into the realm of s 5 . As such, the purpose behind free speech is often better supported by being balanced with the protection of reputation. ${ }^{43}$ Without that balance, "a newspaper just as easily could call a candidate a rapist, an axe-murderer, or an ivory-billed woodpecker". ${ }^{44}$ Ignoring the balance risks "protecting too much inaccurate and harmful reporting". ${ }^{45}$ A society soaked in erroneous and destructive information risks stalling a productive exchange of ideas. Accordingly, the limitation put on false facts that damage reputation is usually justified in a free and democratic society.

36 David Bromwich and George Kateb (eds) John Stuart Mill: On Liberty (Vali-Ballou Press, New York, 2003) at 118.

37 Roth v United States 347 US 476 (1957) at 484.

38 Lyon v Daily Telegraph [1943] KB 746 at 752.

39 United States v Associated Press 52 F Supp 362 (SD NY 1943) at 372.

40 Mitchell $v$ Sprott, above $\mathrm{n} 10$.

41 New York Times v Sullivan 376 US 254 (1964) at 279, n 19.

42 Frederick Schauer "Language, Truth, and the First Amendment: An Essay in Memory of Harry Canter" (1978) 64 Va L Rev 263 at 273.

43 Ollman v Evans 750 F 2d 970 (DC Cir 1984) [Ollman] at 974.

44 Schauer, above n 42, at 289.

45 Abner Mivka "In My Opinion, Those Are Not Facts" (1995) 11 Ga St U L Rev 291 at 299. 


\section{B Scientific Progress}

Within the scope of the marketplace of ideas lies the significance of promoting debate and the exchange of ideas within the fields of science and medicine. In the recent case of British Chiropractic Association v Singh (Singh), science was touted as a sector where opinion should be especially protected. ${ }^{46}$ Dr Singh had written an article in The Guardian's "Comment and Debate" page criticising the British Chiropractic Association (BCA). It alleged that the BCA "happily promoted bogus treatments" and did so without there being "a jot of evidence" to support the effectiveness of those treatments. ${ }^{47}$ Eady $\mathrm{J}$ in the High Court ruled that the allegations were plainly "a matter of verifiable fact". ${ }^{48}$ The Court of Appeal reversed that decision, noting that the High Court ruling had "most certainly had a chilling effect on public debate which might otherwise have assisted potential patients to make informed choices about the possible use of chiropractic". 49

\section{Counter-Balance for Absolute and Qualified Privilege}

The protection of opinion provides a balance to the privileges accorded public officials in regards to statements made in their official duties. ${ }^{50}$ These privileges allow them to "speak freely without fear that what they say will later be held against them in the Courts". ${ }^{51}$ However, without the equivalent freedom to voice opinions, public officials would have an "unjustified preference over the public they serve". ${ }^{52}$ As Brennan $\mathrm{J}$ observed, "analogous considerations support the privilege for the citizen-critic of government. It is as much his duty to criticise as it is the official's duty to administer." 53 Thus, the defence of honest opinion acts as a "brake on the abuse of power by public officials", 54 and exposes individuals to a variety of beliefs, which they then can convey back to the government.

\footnotetext{
46 British Chiropractic Association v Singh, above n 3.

47 At [1].

48 At [14].

49 At [11].

50 Jeffrey Kirchmeier "The Illusion of the Fact-Opinion Distinction in Defamation Law" (1989) 39 Case W Res L Rev 867 at 872.

51 Prebble v Television New Zealand Ltd [1994] 3 NZLR 1 (PC) at 8.

52 New York Times $v$ Sullivan, above n 41, at 282-283.

53 At 282 .

$54 R v$ Secretary of State for the Home Department, ex p Simms [1999] 3 WLR 328 at 337.
} 


\section{Alleviating the Strictness of the Defence of Truth}

The defence of truth ${ }^{55}$ protects the defendant from being sued if the imputations contained in the statements complained of were "true or not materially different from the truth" or if "the publication taken as a whole was in substance true, or was in substance not materially different from the truth". ${ }^{56}$ Although a true statement may still lower a person in the estimation of others, the reason for the truth defence is that it entitles a person "only to the reputation his or her behaviour deserves". 57

Nevertheless, the uncertainty of being able to prove the truth of a statement to a high enough degree to satisfy the courts raises concerns of self-censorship. ${ }^{58}$ As a result, false statements may be deterred but also true ones and opinions. This chilling effect on free speech "dampens the vigour and limits the variety of debate". 59

Without the defence of honest opinion to alleviate it, the truth defence is unsatisfactory and harsh. Justification applies to facts or opinions. ${ }^{60}$ However, subjecting opinion to the same standard of proof as fact would be "a significant inhibition on free speech". ${ }^{61}$ Potential critics may hold themselves only to the "safest" of statements in order to avoid harsh penalties. This risks hindering valuable discussion and criticism through concerns that statements may not "survive the court test of 'truth' even when [there were] reasonable grounds to believe them to be accurate". ${ }^{62}$ The defence of honest opinion then softens the burden of proving truth and encourages discussion and debate. ${ }^{63}$

\section{E Opinions are Less Damaging than Fact}

Aside from the right of free speech, another basis behind honest opinion is the notion that "words which are clearly comment are likely to be treated with more caution by the reasonable

55 Also, "justification". See Milmo and Rodgers, above n 7, at [12.3].

56 Defamation Act 1992, s 8.

57 John Burrows and Ursula Cheer "Defamation" in Stephen Todd (ed) The Law of Torts in New Zealand (6th ed, Thomson Reuters, Wellington, 2013) 809 at [16.9].

58 New York Times $v$ Sullivan, above n 41, at 279.

59 At 279.

60 Milmo and Rodgers, above n 7, at [12.3].

61 At [12.3].

62 Herbert Titus "Statement of Fact Versus Statement of Opinion - A Spurious Dispute in Fair Comment" (1962) 15 Vand L Rev 1203 at 1209.

63 At 1209. 
reader and hence are less damaging than assertions of fact". ${ }^{64}$ A reader will be more wary of an opinion statement since it leaves room for other possible conclusions. For example, "I saw Sam in the office looking around suspiciously. I think he took the money." There is latitude here for the reasonable reader to consider alternatives other than Sam being a thief. Thus, to support the basis of the honest opinion defence, John Burrows suggests a reader should be able to discern when an opinion is being made and "compare it with his or her own". 65

With the purpose of protecting free speech and a belief that opinions are less damaging than fact, the common law courts search for a dividing line between fact and opinion to clarify the defence of honest opinion.

\section{INADEQUACY OF THE FACT-OPINION DISTINCTION}

As the concerns underlying the truth defence indicated, uncertainty in defamation law breeds self-censorship. Accordingly, to support the rationale behind the honest opinion defence, the law must provide clarity and predictability. While the three limbs of the defence, namely honesty, clear indication of opinion and a supplied substratum of facts, are in themselves fairly straightforward, their implementation has proven challenging. Most elusive has been distinguishing facts from opinion in order to determine if the second and third limb has been satisfied.

\section{A Inconsistency in the Courts}

Courts across the common law countries battle with this dichotomy, often resulting in split decisions or similar cases being decided very differently. In the United Kingdom case of Berkoff $v$ Burchill (Berkoff), the defendant was a film critic writing for The Sunday Times. In one review, she wrote that "film directors from Hitchcock to Berkoff are notoriously hideous-looking people". ${ }^{66}$ In another she wrote that the Frankenstein character in the film of the same name was "a lot like Stephen Berkoff, only marginally better-looking". ${ }^{67}$ The Court of Appeal held this gave the impression that Mr Berkoff, a well-known actor, director and writer, was physically repulsive and that, since he was in the public eye and made his living partially as an actor, this meaning was "capable of lowering his standing in the estimation of the public and of making him an object of ridicule". ${ }^{68}$ In his dissenting judgment, however, Millet LJ reasoned that holding this statement as

64 Mitchell v Sprott, above n 10, at [17] citing Patrick Milmo and WVH Rodgers (eds) Gatley on Libel and Slander (9th ed, Sweet \& Maxwell, London, 1998) at [12.7].

65 Burrows and Cheer, above n 8, at [3.2.1(a)].

66 Berkoff v Burchill, above n 1, at 141.

67 At 141.

68 At 151. 
an actionable wrong would be "an unwarranted restriction on free speech", asserting that "[p]eople must be allowed to poke fun at one another without fear of litigation."69

In 1984, Australian food critic Leo Schofield wrote a negative review of the Blue Angel Restaurant, published in the Good Living section of The Sydney Morning Herald. ${ }^{70}$ Schofield lamented that the lobster he had ordered was so appallingly overcooked that it was a "culinary crime" and "so crudely handled as to be, for this diner at least, almost inedible". ${ }^{71}$ Schofield added that the menu noted a 45-minute wait time for the lobster. He went on to describe his lobster as, "cooked until every drop of juice and joy had been successfully eliminated" and that "the carbonised claws contained only a kind of white powder". ${ }^{72}$ The plaintiffs complained of a number of imputations and to three of these Schofield pleaded fair comment. Mr Justice Enderby allowed the defence to go to trial for only one: that the plaintiff "was a restaurateur that charged a price for excellent fresh lobster which when later cooked incompetently ... did not then represent good value". ${ }^{73}$ While the jury agreed that this imputation could be comment, they felt it was not based "on proper material for comment". ${ }^{74}$ As a result, Schofield's defence failed and Blue Angel and its proprietor were awarded a total of $\$ 100,000$ in damages. ${ }^{75}$

In London Artists v Littler (London Artists) ${ }^{76}$ and Jeyaretnam v Goh Chok Tong (Jeyaretnam), ${ }^{77}$ the facts were startlingly similar but contrastingly decided. In the former case, four actors, via identical letters, each gave notice they were leaving a production at the end of the month. The defendant published a letter noting their resignations and stating there was a plot by the four actors to end the running of the play. The statement complained of in London Artists was: "I am hurt that you did not see me before being a party to what, on the face of it, appears to be a plan to close the run of [the play]." ${ }^{78}$ The Court held that this was stated as a fact. Similarly, in Jeyaretnam, the defendant spoke at a press conference, "I believe the exodus was engineered. I don't think it was spontaneous." This was based on an incident that occurred at the inauguration of a political party.

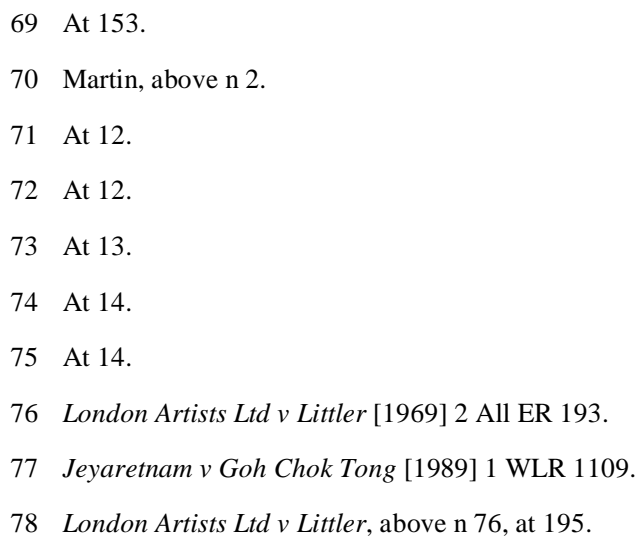


After his speech, Mr Jeyaretnam suddenly left, followed by a walk out by 200 members of the audience. The statements were regarded by the courts as opinion.

\section{B Underlying Problem}

Why then, when the three limbs of honest opinion seem straightforward enough, are the results so erratic? In the cases above, discussion centres on determining whether a statement or statements should be neatly placed in the "fact box" or the "opinion box". Ideally, a test that creates a brightline between fact and opinion would provide the predictability and certainty that the rationale craves. Yet, this clear distinction continues to elude the courts.

A bright-line distinction assumes that fact and opinion statements are opposites and therefore easily divided. ${ }^{79}$ In reality, no bright-line can be determined because the distinction is one of degree. ${ }^{80}$ As Robinson $\mathrm{J}$ noted, "fact is the germ of opinion". ${ }^{81}$ The procession from opinion to fact statements exists on a continuum with progressing degrees of specificity. ${ }^{82}$

While every statement, no matter how specific, will be "in some measure the product of inference and reflection as well as observation and memory", ${ }^{83}$ those at the extreme end of the spectrum contain the least amount. These statements deal with "one's direct sensory perceptions" and will be viewed as "certain and true". ${ }^{84}$ This is especially so with a statement that refers to a tangible object. This object "can be compared with the words used to see if there actually is a correspondence between the object and the words used to describe it". ${ }^{85}$ To say that in the school dining hall is a table with four legs can be resolved with a fair amount of confidence. ${ }^{86}$ This type of statement contains "virtually no inference, synthesis, or opinion". ${ }^{87}$ For the sake of argument and

79 Titus, above n 62, at 1222.

80 Beech Aircraft Corp v Rainey 488 US 153 (1988) at 168.

81 Ollman, above n 43, at 1021

82 Titus, above n 62, at 1222.

83 E Cleary (ed) McCormick on Evidence (3rd ed, West Publishing, St Paul, MN, 1984) at 27. Even facts themselves can be viewed as opinion statements that have been more specifically stated: see Beech Aircraft Corp $v$ Rainey, above $\mathrm{n}$ 80, at 168. Frederick Nietzsche maintained: "There are no facts, only interpretations." Frederick Nietzsche "Aus dem Nachlass der Achzigerjahr" in Werke III at 903, cited by Charles Larmore The Morals of Modernity (Cambridge University Press, Cambridge, 1996) at 81.

84 Titus, above n 62, at 1222 .

85 Schauer, above n 42, at 277.

86 This article does not delve into philosophical arguments as to the existence of matter. For this philosophical discussion, see Bertrand Russell The Problems of Philosophy (Oxford University Press, New York, 1959) at ch 2 .

87 Schauer, above n 42, at 278 . 
the need to distinguish one end of the spectrum from another, comparing a statement to a physical object could be called a "pure fact". Moving along the continuum, verifying a statement against established scientific principles, such as the detrimental physical effects of consuming large quantities of fast food, would be less precise but still well within the realm of general acceptance. ${ }^{88}$

At the other end of the spectrum lie statements of "pure opinion". These statements cannot be compared to objects that are observed or experienced through senses. They cannot even be verified against accepted criteria, since "the notion of confirming a statement purely of personal belief is nonsensical". ${ }^{89}$ Often these statements will refer to the "existence of God or the nature of knowledge", ${ }^{90}$ or to matters of personal taste, political views or literary criticism. Sitting on the continuum just before these pure opinion statements are those Robinson $\mathrm{J}$ in Ollman $v$ Evans referred to as "derogatory remarks [or] ... expressions of generalised criticism or dislike without any specific factual moorings". ${ }^{91}$ In this area would also fall metaphorical statements, which through context are clearly being used figuratively rather than literally. ${ }^{92}$ Robinson $\mathrm{J}$ provides an example where the plaintiff was said to "run a paper by paranoids for paranoids". ${ }^{93}$ Read in context, the statement in that case was described as "obviously used ... in a loose, figurative sense ... [and could not] be construed as representations of fact". ${ }^{94}$

The fundamental problem with the fact-opinion distinction is that many statements fall somewhere on a continuum between strictly fact and strictly opinion. They often contain varying elements of fact, inference, reflection or emotion. It is in this mid-range of the spectrum that the three types of statements mentioned earlier exist. ${ }^{95}$

\section{The intermingled statement}

An opinion statement that is not plainly separated from the facts surrounding it may be understood by the reader to be just another fact based on adequate grounds known to the writer. ${ }^{96}$ In the Canadian case of Mitchell $v$ Times Printing and Publishing Co Ltd, the Victoria Daily Times

88 At 278

89 At 278

90 Michelle Sanders "The Fact/Opinion Distinction: An Analysis of the Subjectivity of Language and Law" (1987) 70 Marq L Rev 673 at 680.

91 Ollman, above n 43, at 1021.

92 At 1022 .

93 At 1022, citing Loeb v Globe Newspaper Co 489 F Supp 481 at 486 (1980).

94 Loeb v Globe Newspaper Co 489 F Supp 481 at 486 (D Mass 1980).

95 See Part II - Law of Honest Opinion.

96 Milmo and Rodgers, above n 7, at [12.13]. 
published an article imputing that the arrest of Mitchell solved the murder mystery of Molly Justice. ${ }^{97}$ It continued on to say that the police had looked for Mr Mitchell for a lengthy period and that he was brought in on a "boy sex" charge which led to the "uncovering [of] Justice murder facts". 98 The only points made in the article which were actually true were that Mitchell was arrested and charged with murder and he had been booked on a boy sex charge. ${ }^{99}$ The paper raised the defence of fair comment, applying it to the statements that could not be proven true. ${ }^{100}$ Bird J noted that while the article was a mixture of opinion and fact, it was not clear to him which statements were intended as which. Nor was it likely to be clear to the reasonable reader. ${ }^{101}$

\section{The inference of fact statement}

While a statement that sets out a value judgement may be apparent as opinion, one that "contains an inference of fact" 102 may be more uncertain. This type of statement looks like a fact statement. However, it may be a fact stated as an "inference drawn by the writer from other facts" and would accordingly be treated like an opinion. ${ }^{103}$ Gatley on Libel and Slander gives the example: "Jones took a bribe." 104 If the writer had indicated in his article the events that led to this conclusion and indicated that this was his own personal conclusion, the defence may be available to him.

\section{The bald statement}

A "bald statement", such as "X is dishonourable", is one that does not identify the facts upon which it is based. Although it may look like an opinion, it will often be categorised as a fact because it gives no indication that it is a conclusion drawn from other facts. Without the facts to base the statement on, the reader would likely interpret it as a fact. ${ }^{105}$ However, some authorities are concerned that labelling bald statements as "fact" may be misleading. ${ }^{106}$ Lord Phillips suggests this

97 Mitchell v Times Printing and Publishing Co Ltd (No 2) [1944] 1 WWR 400.

98 At [1].

99 At [16].

100 At [17]

101 At [33].

102 Burrows and Cheer, above n 8, at [3.2.2].

103 Milmo and Rodgers, above n 7, at [12.6].

104 At 12.6 .

105 Lowe v Associated Newspapers Ltd [2006] EWHC 320 (QB).

106 Joseph $v$ Spiller, above n 19, at [5] per Lord Phillips; Burrows and Cheer, above n 8, at [3.2.2], n 412. 
type of statement is "a comment coupled with an allegation of unspecified conduct upon which the comment is based". ${ }^{107}$

\section{Supporting the Rationale}

The examples above indicate that the current method does not adequately support the rationale behind the honest opinion defence. First, there is a struggle to attain the predictability and certainty needed to prevent self-censorship. ${ }^{108}$ Reviewers may be reluctant to critique restaurants negatively for fear of spending the next eight years in court battles. Scientists may keep thoughts to themselves on new or contentious theories. Even a case decided in favour of the defendant can cause a chill on speech, especially if it has gone through several courts or was not decided unanimously.

Secondly, the examples indicate that opinions are not necessarily less damaging than fact. ${ }^{109}$ This rationale is in itself problematic. Opinions play a powerful role in society. Some of the most significant events in people's lives are based on opinions: marriage, choice of religion, choice of career, to name a few. ${ }^{110}$ Furthermore, suggesting that factual statements are more harmful ignores the point that often "facts by themselves are innocuous". ${ }^{111}$ If, for example, Emma gets one minute, 20 seconds in her 100 metre freestyle swim, this reflects nothing on its own. Without an opinion attached to it, there is no indication whether that is good or bad. Or if Jack buys wires and solder from the local hardware shop, this is simply a neutral statement. However, suggest he is there to get ingredients for a bomb and he could be in serious trouble.

Some situations can generate opinions that have a ruinous impact. Consider the communicator: "Identical words, in the mouths of different persons, can carry a radically different weight." 112 For instance, some statements made by socially weak groups can be ineffective in contrast with statements made by more powerful ones. ${ }^{113}$ The effect a statement will have can depend on how favourably disposed an audience is towards the communicator. ${ }^{114}$ Along that same vein, an opinion

107 Joseph $v$ Spiller, above n 19, at [5].

108 Eric Barendt, Laurence Lustgarten, Kenneth Norrie and Hugh Stephenson Libel and the Media: The Chilling Effect (Oxford University Press, Oxford, 1997) at 190.

109 Interestingly, while the 9th edition of Gatley on Libel and Slander, above n 64, at [12.7], stated that opinions are less damaging, this was removed in the 11th edition.

110 Jerry Phillips "Opinion and Defamation: The Camel in the Tent" (1990) 57 Tenn L Rev 647 at 656.

111 At 669 .

112 David Riesman "Democracy and Defamation: Fair Game and Fair Comment II" (1942) 42 Colum L Rev 1282 at 1306 .

113 At 1306.

114 Titus, above n 62, at 1212 . 
made by someone highly respected or with expertise, such as a doctor or lawyer, can notably influence others.

Another consideration is the person about whom the communication is being made. In the case of Gacic v Fairfax, a food critic reviewed an extremely high-end and expensive restaurant. ${ }^{115}$ Those eating there would expect near-perfection. The review described the food as "unpalatable". ${ }^{116}$ This could cause many readers to shun the restaurant. When paying for expensive food, readers are less likely to want to risk getting an unpalatable meal.

\section{CURRENT TESTS}

The struggle for clarity and predictability has led to much discussion across the common law countries regarding tests to distinguish fact from opinion.

\section{A Perception of the Reader Test}

As noted earlier, New Zealand and the United Kingdom view the statement from the perception of the reasonable reader and consider varying factors as to the context in which it was stated. The Supreme Court of Canada adopted a similar test: "What is comment and what is fact must be determined from the perspective of a 'reasonable viewer or reader'."117

However, this test has not defined what a "fact" or "opinion" statement is. ${ }^{118}$ Saying that the statement is an opinion if it is read as an opinion is circular. ${ }^{119}$ The terms "fact" and "opinion" are used so vaguely that nearly any conclusion sought could be made to fit. ${ }^{120}$ On its own, the test becomes self-justifying and thus, neither helpful nor predictable.

A survey of the United States courts yields more variety and discourse surrounding the debate. Two tests emerge with frequency: the "verifiability" test and the "totality of circumstances" test.

\section{$B$ Verifiability Test}

The verifiability test attempts to find the distinction between actionable and protected statements by first assessing whether the statement has a "generally accepted core of meaning". ${ }^{121}$ If it does,

115 Gacic v John Fairfax Publications Pty Ltd [2011] NSWCA 362.

116 Matthew Evans "Crash and Burn: When dining on the view is the only recommendation" The Sydney Morning Herald (Sydney, 30 September 2003) at 6 .

117 WIC Radio Ltd v Simpson [2008] 2 SCR 420, 2008 SCC 40 at [27].

118 Titus, above $\mathrm{n} 62$, at 1205

119 Jeffrey Thomas "Statements of Fact, Statements of Opinion, and the First Amendment" (1986) 74 Cal L Rev 1001 at 1011, n 69.

120 Titus, above n 62, at 1205 .

121 Thomas, above n 119, at 1017. 
then the question is asked whether the statement is capable of proof or disproof by an objective standard. One that is capable of that proof will be considered a "factual statement". ${ }^{122}$ The reasoning is that if a statement is not verifiable, it cannot be considered to convey actual facts and thus, cannot be actionable in defamation because of constitutional protections of opinions. ${ }^{123}$

In some instances the verifiability test is used as an alternative to distinguishing fact from opinion. ${ }^{124}$ The Supreme Court in the United States concluded that protecting free speech can be accomplished "without the creation of an artificial dichotomy between 'opinion' and fact". ${ }^{125}$ In Milkovich v Lorian Journal Co (Milkovich), the majority held that statements must be "provable as false before there can be liability under state defamation law". ${ }^{126} \mathrm{Mr}$ Milkovich was a high-school wrestling coach in Ohio. During a home match a fight broke out, causing Milkovich's team to be put on probation by the Ohio High School Athletic Association (OHSAA). Several parents sued the OHSAA. The Court of Common Pleas overturned the probation. Mr Diadiun wrote in his News Herald article, "Anyone who attended the meet ... knows in his heart that Milkovich ... lied at the [Court of Common Pleas] hearing after ... having given his solemn oath to tell the truth." ${ }^{127} \mathrm{Mr}$ Milkovich sued, alleging the statement that he had committed perjury was defamatory.

The majority held that because Mr Milkovich's testimony before the OHSAA and his testimony before the Trial Court could be compared, the statement was "sufficiently factual to be susceptible of being proved true or false". ${ }^{128}$ While Brennan and Marshall JJ agreed with the majority's theory, they disagreed with its application. In looking at the context of the News Herald article, they found the statements could not imply, as a verifiable fact, "that Milkovich had perjured himself". ${ }^{129}$ Whether the verifiability test is perceived as a method of distinguishing fact from opinion or whether it is a separate test to indicate a statement as an actionable wrong, the test creates the same issues of uncertainty as the "perception of the reader" test.

Many statements do not "divide neatly into categories of 'verifiable' and 'unverifiable"'. ${ }^{130}$ Most statements will fall somewhere along a spectrum of differing degrees of verifiability. ${ }^{131}$ The more

\section{At 1017.}

123 David Becker "Structuring Defamation Law to Eliminate the Fact-Opinion Determination: A Critique of Ollman v Evans" (1986) 71 Iowa L Rev 913 at 924.

124 For example, see Hotchner v Castillo-Puche 551 F 2d 910 (2d Cir 1977) at 913.

125 Milkovich v Lorian Journal Co 497 US 1 (1990) at 19.

126 At 2706 .

127 At 2698.

128 At 2707.

129 At 2711.

130 Ollman, above n 43, at 982. 
verifiable a statement is, the "more confident the determinations of truth". ${ }^{132}$ For example, a statement that one owns a home in New Zealand is verifiable, whereas a statement that " $\mathrm{X}$ is frightening" is not. One can be more confident of the truth of the former statement than the latter. While being critical of an over reliance on this test, some courts have acknowledged its limited usefulness, as a "minimum-threshold issue". ${ }^{133}$ As with pure opinion statements, the test may be helpful in recognising where a statement sits at the extreme ends of the continuum.

The marketplace of ideas metaphor, which underlies arguments for free speech and the defence of honest opinion, relies on the ideas brought forward in John Stuart Mill's On Liberty. ${ }^{134}$ Ironically, the reason Mill felt opinions should be protected was not because of their inability to be verified but rather because since they could often be proven true, they have a valuable place in society. Even partially true opinions could lead to important discussion and clashes of opinion, allowing "the remainder of the truth ... any chance of being supplied". ${ }^{135}$

Another difficulty emerges when the test is used on its own. For example, consider a restaurant review that states, "The green peppers ... remained frozen on the plate." 136 While this could be proven true or false, because it is in a restaurant review, the reader is most likely to understand it as an opinion. ${ }^{137}$ As a single inquiry, verifiability may yield one result but when the scope of the test is widened to include context, another determination often results. This recognises that the "meaning of words vary depending on the immediate context of the words and the social setting of the statement". ${ }^{138}$ Some courts have opted to use this test in combination with other tests.

\section{Totality of Circumstances Test}

One court that did so was the Court in Ollman v Evans (Ollman). ${ }^{139}$ There the Court developed the four-factor "totality of circumstances" test to determine if a statement was an actionable fact or a protected opinion. The first factor determines whether the statement has a precise commonly understood meaning that gives rise to factual implications. The second looks at whether the

131 At 982; Schauer, above n 42, at 279.

132 Schauer, above n 42, at 279.

133 Potomac Valve \& Fitting Inc v Crawford Fitting Co 829 F 2d 1280 (4th Cir 1987) at 1289.

134 Phillips, above n 110, at 659.

135 Bromwich and Kateb, above n 36, at 118.

136 Mr Chow of New York v Ste Jour Azure SA 759 F 2d 219 (2nd Cir 1985) at [13].

137 At [46].

138 Becker, above n 123, at 925.

139 Ollman, above n 43. 
statement is verifiable. The third and fourth factors look to context, namely the immediate context in which the statement occurs and the broader social context surrounding the statement.

The development of a test with factors that look to the statement itself and the context within which it sits provides some structure for courts to follow and retains the flexibility needed to analyse different types of statements and situations. However, even within Ollman there was disagreement with the test's application. Once again, despite applying the same test, the Court was split as to whether that test revealed the statements as fact or opinion. Differing views on what was contextually relevant and how much weight should be given to those factors caused some of the divide. ${ }^{140}$ Additionally, Wald $\mathrm{J}$ in his dissent felt that the statement in that case yielded a precise commonly understood meaning that could be verified. ${ }^{141}$

The United States Supreme Court in Milkovich superseded Ollman. By ignoring the context factors from Court of Appeal's test, the Supreme Court looked at statements in their literal form. ${ }^{142}$ This is less ideal in that it makes the defence harder to obtain and does not recognise the reader's ability to interpret a statement as an opinion based on its contextual environment. ${ }^{143}$ It also is undesirable to ignore the environment in which the statement exists as this can lead to an artificial determination of fact or opinion. Dissatisfaction with the Milkovich test is most evident in the case of Moldea $v$ New York Times Co, ${ }^{144}$ which initially followed Milkovich. Just three months later, in a unique turnabout, the same panel of Court of Appeal judges reversed its decision, stating that context was a critical consideration. ${ }^{145}$

140 At 1034 per Wald J: "[T]he immediate context in which this statement was made does little to warn a reader to regard with scepticism what might otherwise appear to be an assertion of fact."

141 At 1032.

142 Milkovich v Lorian Journal Co, above n 125, at 21; Margaret Chan "Importance of a Contextual Approach to Libel Law: The Impact of Immuno AG v Moor-Jankowski and Milkovich v Lorain Journal Co" (1993) 9 Touro L Rev 611 at 618.

143 Milkovich v Lorian Journal Co, above n 125, at 18; Nancy K Bowman "Milkovich Meets Modern Federalism in Libel Law: The Lost Opinion Privilege Gives Birth to Enhanced State Constitutional Protection" (1993) 42 DePaul L Rev 583 at 585.

144 Moldea v New York Times Co 15 F 3d 1137 (DC Cir 1994) [Moldea I].

145 Moldea v New York Times Co 22 F 3d 310 (DC Cir 1994) [Moldea II] at 313-314; Abner Mivka, above n 45, at 300. Regarding disapproval of Milkovich v Lorian Journal Co, above n 25, see also Lisa Herskowitz "One Bad Bit of Dictum Deserves Another: Gertz and Milkovich" (1992) 24 Conn L Rev 1159; Chan, above n 142; Lisa West "Milkovich v Lorain Journal Co - Demise of the Opinion Privilege in Defamation" (1991) 36 Vill L Rev 647; John B Cromer "Milkovich v Lorain Journal Co: This Opinion May Stifle Yours" (1991) 20 Cap U L Rev 498. 


\section{Further Inconsistency in the Courts}

While contextual factors are sometimes considered in the United Kingdom and New Zealand courts, they are not done so consistently nor are the same factors considered across all cases. For example, in London Artists, the Court felt the use of cautionary language was not strong enough to convey the statements as opinion. ${ }^{146}$ By contrast, in Jeyaretnam, the statement, "I am inclined to believe", was instrumental in the Court of Appeal deciding that the statements were opinion. That judgment did not reflect on the fact that the statement was made in a press conference, which could suggest a vessel for imparting news and facts rather than opinions. ${ }^{147}$

To most, a value judgement regarding someone's appearance is likely to fall on the extreme opinion end of the spectrum. In Berkoff, the majority ignored any possibility that the statement implying Berkoff was hideously ugly was an opinion. However, Millet LJ, in his dissent, considered the contextual factor that the author was writing in her role as a film critic, allowing for the statement to be understood as a humorous exaggeration. ${ }^{148}$

In Singh, the fact that the statements made were of a scientific or medical nature influenced the Court of Appeal to overturn the High Court decision and rule in favour of the defendant. ${ }^{149}$

Hence, different cases regard different factors when assessing whether a statement is a fact or opinion. ${ }^{150}$ The result is an inconsistent and unpredictable defence that risks courts picking and choosing the factors to accord with a desired outcome, arguably infringing upon the rationale behind the defence.

\section{BALANCING VALUES}

In some situations, the restrictive nature of defamation law does not allow the defence of honest opinion enough scope, thus unjustly punishing speech. In others, the uncertainty and incoherency of the law hinders free speech through a chilling effect, even before it reaches the courts. The rationale underlying the defence of honest opinion is then left unsupported: the marketplace of ideas becomes barren, scientific progress is stilted and opportunities to challenge officials are left ungrasped. The lack of guidance by current tests creates a concern under the New Zealand Bill of Rights Act 1990 (NZBORA). The common law is required to reflect the NZBORA ${ }^{151}$ and an incoherent law, vague

146 London Artists Ltd v Littler, above n 76, at 392.

147 Jeyaretnam v Goh Chok Tong, above n 77.

148 Berkoff v Burchill, above n 1, at 153.

149 British Chiropractic Association v Singh, above n 3, at [26]; Eric Barendt "Science Commentary and the Defence of Fair Comment to Libel Proceedings" (2010) 2 JML 43 at 45.

150 Herskowitz, above n 145, at 1173.

151 Hosking v Runting [2005] 1 NZLR 1 (CA). 
and unpredictable as defamation law is, will be unable to provide a demonstrably justifiable limit on free speech that is prescribed by law as per s 5 of the NZBORA.

The "prescribed by law" element requires any limit to be imposed by a law that is "adequately accessible" and expressed with "sufficient precision". ${ }^{152}$ This aims to provide the public with the ability to foresee the legal ramifications of their actions and conduct their behaviour accordingly. ${ }^{153}$ Thus any limitation against a freedom or right must be balanced on "a clear and transparent basis" in order to be demonstrably justifiable. ${ }^{154}$ While freedom of expression is often considered our most highly valued freedom, it cannot be regarded as a "universal social panacea ... trumping other rights". ${ }^{155}$ Limitations must be put in place in order to allow other rights and freedoms to coexist along with free speech. However, for a proper balance to be created between competing values, any limitation on free speech must be "reasonable and demonstrably justified". 156

In Hosking $v$ Runting, Tipping J noted that the question to ask in determining if a particular limit on expression is demonstrably justifiable is "whether individual harm outweighs public good". ${ }^{157}$ This concept of proportionality was discussed in $R v$ Hansen. ${ }^{158}$ In order for a limit to be justified under $s 5$, it must be proportionate to the importance of the freedom or right. ${ }^{159}$ Thus, the high value placed on free speech requires any limitation on that freedom to be of equal or greater importance. Individual harm, then, in the form of damage to reputation, must be significant in order to outweigh the public good of free speech. That is, the protection from the harm must be a legitimate interest needed by society. ${ }^{160}$ Often courts have been found to limit speech when the harm was arguably not proportionately significant, as in Berkoff for example, ${ }^{161}$ resulting in an overly restrictive outcome. More generally, however, the unpredictability of the law that results in self-censorship creates its own limitation on free speech. ${ }^{162}$ That limit is also arguably not

152 Sunday Times v United Kingdom [1979] ECHR 1, (1979) 58 ILR 491 at [49]. See also Ministry of Justice "Part II: Initial Considerations When Applying the Bill of Rights Act" < www.justice.govt.nz>; Ministry of Transport v Noort [1992] 3 NZLR 260 (CA).

153 Sunday Times $v$ United Kingdom, above n 152, at [49].

154 Ministry of Justice, above n 152.

155 Hosking $v$ Runting, above n 151, at [231] per Tipping J.

156 At [233] per Tipping J.

157 At [236].

$158 R v$ Hansen [2007] NZSC 7, [2007] 3 NZLR 1.

159 At [123].

160 At [186].

161 Berkoff v Burchill, above n 1, at 153.

162 Barendt, Lustgarten, Norrie and Stephenson, above n 108, at 190. 
proportionate since no harm has yet occurred, significant or otherwise, nor has the limitation occurred due to any thought of balancing proportionality. It has simply been self-protection. This limitation then does not comply with the "prescribed by law" element of s 5, since it occurs directly as a result of the law lacking clarity and predictability. Consequently, a law that widens the scope of the defence of honest opinion and provides more certainty and predictability would be more consistent and better comply with the NZBORA.

\section{SOLUTION}

The description from Clarke $v$ Norton, referred to earlier, allows for a broad scope of statements that could fall under the category of opinion: "something which is or can reasonably be inferred to be a deduction, inference, conclusion, criticism, remark, observation, etc". ${ }^{163}$ In the past, courts considering this list have tended to rule in favour of free speech by granting the defence. ${ }^{164}$ However, in relying on the definition, courts still find themselves searching for a distinctive line between fact and opinion, as in Gough $v$ Local Sunday Newspapers. ${ }^{165}$ There, Gray J, after using Clarke $v$ Norton as a base point, went on to differentiate fact from opinion by concluding that fact can be "proved or disproved ... whereas comment cannot". ${ }^{166}$ The drawbacks to using verifiability as a bright line have already been discussed. Thus while the Clarke $v$ Norton list provides for a wider category of statements that could be considered opinion, it still lacks the necessary guidance to determine whether the statement would be perceived by the reasonable reader as falling under that category of deduction, inference, criticism, remark or observation. Without that guidance, the certainty required to measure any limitation against a freedom in a demonstrably justifiable way is left wanting.

The Ollman test utilises four factors, which aim to provide the courts with more guidance. However, one of the difficulties with the Ollman test may be that those factors are still too general. Determining what should be considered within each factor and the weight it should carry becomes "largely subjective". ${ }^{167}$ It is likely that no one test could be created that would definitively discern a fact from opinion in each of the infinite possible scenarios. However, the Ollman test is a strong contender and can be used to supply a framework for a more specific set of factors. These would provide more clarity, predictability and consistency for the defence of honest opinion in New

163 Clarke v Norton, above n 15, at 499.

164 See for example Branson v Bower [2001] EMLR 32; Skrine \& Co v Euromoney Publications [2002] EMLR 15; Rath v Guardian News and Media Ltd [2008] EWHC 398; Massie v McCaig [2013] CSIH 14.

165 Gough v Local Sunday Newspapers (North) Ltd (No2) [2002] EWHC 336 at [89].

166 At [89].

167 Herskowitz, above n 145, at 1173. 
Zealand. ${ }^{168}$ Notably, many of these factors have been considered at one time or another in various judgments in the United Kingdom and New Zealand but rarely in their entirety, and often erratically. While it must be conceded that situations will still arise where courts will disagree in ascertaining whether a statement is a fact or opinion, the proposed eight-factor test would also widen the availability of the defence, thus better supporting freedom of expression by limiting it only for clear and justified circumstances, in accordance with the NZBORA.

The proposed test would seek to answer an overarching question similar to that already asked by New Zealand courts: "Is the statement presented in such a way that the reasonable reader would recognise it as an opinion?"

While the question by itself is circular, a series of factors would in most circumstances guide the courts to an answer by helping them ascertain where on the spectrum of fact-opinion the statement lies. The first two factors look to the statement itself.

\section{A Common Usage}

Is the statement one that has a precise commonly understood meaning? ${ }^{169}$

This factor gives the court a starting point on the fact-opinion spectrum. As other factors are considered, the statement may be adjusted along the spectrum one way or another.

Some statements are clearly understood as having one meaning and as such will carry factual implications. Saying someone is a thief would generally have one understood meaning: the person has stolen another's property. However, a further look at other factors, such as the context that the statement is in, may expose a figurative meaning, indicating this particular statement may be understood by the reader as an opinion.

\section{B Extent to which the Statement is Verifiable Scientifically}

While the second Ollman factor is one of verifiability, the concern is that this factor increases uncertainty. As stated above, verifiability can be difficult to determine and is often a subjective determination. Indeed, two judges applying the same four-factor test in Ollman came to opposite results because of differing views on the verifiability of part of the statement. ${ }^{170}$

Changing this factor to look at the extent that a statement is provable recognises the spectrum of verifiability mentioned earlier. This allows for a determination by degree. The greater the extent to

168 The proposed test differs from Ollman in that its second and third factors replace the Ollman verifiability factor. Additionally, the context factors in Ollman are separated out to give more clarity and structure to the test.

169 Ollman, above n 43, at 980 .

170 Ollman, above n 43, at 990, n 42 per Judge Starr. Contrast at 1033 per Wald J. 
which the statement is verifiable, the more likely, in light of the other factors, that it is a factual statement.

In recognising a statement to be a fact or opinion, "[r]eaders will inevitably be influenced by a statement's context." ${ }^{171}$ The remaining factors look to the context of the statement.

\section{Extent to which, if the Statement is not Verifiable Scientifically, it is Comparable against an Implicit or Explicit Societal Standard}

Inherent in opinion statements is that they are some form of evaluative judgement, whether a conclusion, justification or even an observation, which is held by the communicator to some standard. If that standard is evident or is made evident, then this may further indicate an opinion. ${ }^{172}$

A standard may be evident if the communicator provides information as to why they are making the statement. This is closely linked to providing a substratum of facts. A test that encourages the communicator of an opinion to explain why he or she is coming to that conclusion will do two things: first, make it clearer that the statement is an opinion and second, allow readers to decide if they agree or disagree with the statement. The latter effect goes to the heart of the defence. If a reader understands clearly that she could disagree with the statement, that statement will encourage debate and discussion and thus should be protected.

Additionally, an indication of a unique standard, whether implicit or explicit, may suggest an opinion. For example, the statement, "Jones is an alcoholic" on its own may give the impression of a fact. However, if the reader is imparted with information indicating that the communicator vehemently considered all alcohol to be sinful and immoral, then that unique standard may indicate the statement to be an opinion.

\section{Language Surrounding the Statement}

Does the language surrounding the statement influence the way the statement is perceived?

A statement, which viewed in a vacuum would appear as a fact, may give the perception of opinion when viewed in the context of the remaining article. For example, in the New Zealand case of Awa $v$ Independent News Auckland Ltd, the term "body-snatcher" was used. The Court in looking at the rest of the article held that "body-snatching" was not meant to suggest improper purpose or dishonesty but merely that the body was removed against the wishes of the widow. ${ }^{173}$

171 At 982. See also Rodney Ott "Fact and Opinion in Defamation: Recognizing the Formative Power of Context” (1990) 58 Fordham L Rev 761.

172 For discussion on requiring that the standards on which the statement is based be set out in order to determine if reasonable care was taken in making that statement, see Titus, above $\mathrm{n}$ 62, at 1228 .

173 Awa v Independent News Auckland Ltd, above n 14, at 594. 


\section{E Cautionary Language}

While not definitive on its own, ${ }^{174}$ phrases such as "I believe" or "in my opinion" can provide an indication to the reader that the statement was intended as an opinion.

\section{F Location of Article or Discourse}

This factor looks to see if the statement is located in a context where rhetorical hyperbole would be expected. For example, in the United States Supreme Court case of Letter Carriers v Austin, the plaintiff was called a traitor. The Court there reasoned that as this was in the course of labour disputes, this type of "exaggerated rhetoric was commonplace". ${ }^{175}$ Additionally, if the article were published in a "comment" section of the paper, it would be more likely to be perceived as containing opinion statements than one placed on the front page.

\section{G Type of Article or Discourse}

Some types of articles clearly indicate that the opinion of the author is being set out, such as restaurant or film reviews. Communication in a press conference, for example, would be more likely to be understood as factual than that on a late night talk show.

\section{H Issues of Public Importance}

Public interest is not a requirement under the defence. However, certain speech should encourage courts to be more lenient towards determining a statement to be an opinion. Statements such as scientific, medical or political speech play an important role in the marketplace of ideas, for example. This is echoed in the aforementioned recent changes to the Defamation Act 2013 (UK) and in the United Kingdom decision of Singh. ${ }^{176}$

\section{Application}

Applying the test to the forms of statements and previous cases that were discussed earlier, demonstrates how the test will work.

In Blue Angel, ${ }^{177}$ the statement that the lobster was "cooked incompetently" could hold a range of meanings from clumsily handled to inexpert. Thus to begin, the statement is on the opinion end of the spectrum. The extent that the phrase, which is one describing personal taste, is unverifiable supports this placement on the spectrum. The third factor recognises the author as a food critic and as such may be presumed by the reader to have a well-developed palate and high standards. The

174 "[A] statement which is plainly one of fact cannot be transformed into one of opinion merely by prefacing it with the words 'in our judgment'": Turner v Metro-Goldwyn-Mayer Pictures Ltd [1950] 1 All ER 449 at 474.

175 Letter Carriers v Austin 418 US 264 (1974) at 2871.

176 Defamation Act 2013 (UK), s 6; British Chiropractic Association v Singh, above n 3, at [26].

177 See Martin, above n 2. 
reader would be more likely to interpret his statement as one which the reader could well have disagreed with if they had eaten the same meal. The article surrounding the statement describes $\mathrm{Mr}$ Schofield's impressions of the rest of his meal. These are evaluative statements, which would further lend the statement complained of an impression of opinion. While no cautionary language is used in this statement nor is it regarding a scientific, medical or political issue, these factors are not strong enough to shift the statement from the opinion end of the spectrum. Finally, the article was located in the Good Living section of The Sydney Morning Herald rather than being front page news and was clearly a restaurant review. By addressing these factors, courts would likely come to the same conclusion: the statement was presented in such a way that the reasonable reader would recognise it as opinion.

The Berkoff decision could have benefited from a set of factors to address. It is difficult to imagine a more obvious statement of opinion than an aesthetic evaluation. The term "hideously ugly" can carry a different meaning to each person and will fall on the extreme end of being unverifiable. Ms Burchill made the statement in her role as a film critic, adding an impression of opinion to an already personal viewpoint. Moreover, the words surrounding the statement were providing an opinion on films and their directors. The statement itself was clearly in the vein of a "humorously exaggerated observation". ${ }^{178}$

\section{Implementation}

While courts have the ability, within the constraints of the legislation, to develop the common law by applying the proposed test, it would add consistency and predictability, ${ }^{179}$ and thereby better comply with the NZBORA, if it were inserted as a separate section into the Defamation Act 1992:

\section{A Factors in determining opinion}

(1) In any proceedings for defamation in respect of matter that includes or consists of an expression of opinion, a defence of honest opinion by a defendant shall fail unless the defendant proves that the statement is presented in such a way that the reasonable reader would recognise it as opinion, having regard to the following factors -

(a) Whether the statement has a commonly understood meaning indicating factual or evaluative implications; and

(b) The extent to which the statement is verifiable scientifically; and

(c) The extent to which, if the statement is not verifiable scientifically, it is comparable against an implicit or explicit standard; and

178 Berkoff v Burchill, above n 1, at 153.

179 For example, the decision in Berkoff $v$ Burchill, above $n$ 1, would likely have been far different had the Court there been required to address these factors. 
(d) The extent to which the language around the statement influences the way the statement is perceived; and

(e) The extent to which cautionary language is used; and

(f) The location of the article or discourse; and

(g) The type of article or discourse.

(2) In any proceedings for defamation in respect of matter that includes or consists of an expression of opinion, the court shall, in the process of considering the factors in section 9A(1), not unduly restrict statements referring to issues of public importance.

\section{FURTHER CONSIDERATIONS}

The focus of this article is on securing a method that could better distinguish opinion from fact. The proposed test, while providing greater clarity, certainty and scope for the defence than current methods, may still be exposed to some justifiability issues because the law itself does not focus on harm. This arguably allows for situations that restrict speech, which may not be doing any harm at all. To address this, another issue could be further explored within the defence. While a detailed investigation is beyond the scope of this article, brief observations may be addressed.

In 1962, Herbert Titus formed his own solution to the fact-opinion dichotomy. ${ }^{180}$ While that solution is not directly adaptable to the modern New Zealand defence of honest opinion, the principles and philosophy behind it are informative. To indicate that his statement would not lower the plaintiff's reputation without justification, Titus felt that the communicator must show he had taken reasonable care in gathering information about the plaintiff and that his statement was justifiable in light of those facts gathered. ${ }^{181}$ The reasonable care aspect embodies a principle of moral duty and responsibility to others within society.

Given the potentially formidable power individuals have through online forums and other methods of instant global communication, ${ }^{182}$ consideration should be given in some way to the effect a statement will have on a given individual. A possible strategy could be to add a second limb to the proposed test, the purpose of which would be to focus on and encourage responsible communicating. This limb would recognise that opinion statements can, in some instances, cause more harm than factual ones. It could be assessed through a NZBORA inquiry: ${ }^{183}$ whether the harm

180 Titus, above n 62

181 At 1228.

182 Twitter, for example, provides the perfect conditions for a heedless "140-characters-or-less" comment to contact thousands of readers, who in turn pass it on to thousands of others. A plaintiff's reputation can be destroyed in minutes.

183 New Zealand Bill of Rights Act 1990, s 5. 
that has resulted, or is likely to result, from the statement is a demonstrably justifiable reason to limit that statement.

Some factors the limb could consider that may increase the harm a statement may cause include:

(a) The probability that the statement has to mislead the reader: "Where that probability is high, a greater number of people will think worse of the plaintiff for reasons other than those which the defendant has relied upon". ${ }^{184}$ This would further look at the standards against which the statement was made.

(b) Potentially some of the same factors that are looked at in determining remedies could also be used in determining whether the harm done was enough to push the statement over the demonstrably justifiable threshold. For example, where the defendant has a great influence over the public or where the nature of the defamatory statement is a serious allegation, the harm will likely be greater.

The challenge in implementing this second limb would be to not undermine the honest opinion defence by causing more uncertainty or by requiring such care be taken before any statement is made that it has a chilling effect on speech.

\section{CONCLUSION}

The unfeasible pursuit of a distinction between fact and opinion casts the law of defamation into a "chilling" world of uncertainty. A society unable to understand and predict when they are free to speak their mind will create self-censorship, hindering the positive public interest effects of debate and discussion, as was seen in Singh. ${ }^{185}$ The proposed test would more effectively provide foreseeable results for communicators while giving the courts a flexible approach that better reflects the fluidity of language and allows the defence to play its intended role as the hallmark of free speech.

184 Titus, above n 62, at 1236 .

185 British Chiropractic Association v Singh, above n 3, at [11]. 
